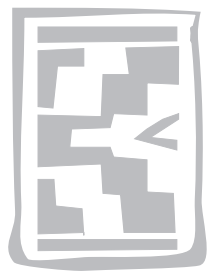

\title{
Trends in the control of heartwater
}

\author{
B.A. ALLSOPP \\ Department of Veterinary Tropical Diseases, Faculty of Veterinary Science, University of Pretoria \\ Private Bag X04, Onderstepoort, 0110 South Africa
}

\begin{abstract}
ALLSOPP, B.A. 2009. Trends in the control of heartwater. Onderstepoort Journal of Veterinary Research, 76:81-88

Heartwater is an economically serious tick-borne disease of ruminants caused by the intracellular bacterium Ehrlichia ruminantium. The disease has traditionally been controlled by four different approaches: controlling the tick vector by dipping, establishing endemic stability, performing immunisation by infection and treatment, and preventing the disease by regular administration of prophylactic antibiotics. The first three of these methods are subject to failure for various epidemiological reasons, and serious disease outbreaks can occur. Prophylaxis is effective, but very expensive, and the logistics are daunting when large herds of animals are involved. The development of a safe, cheap and effective vaccine is the only likely way in which heartwater can be economically controlled, and over the past 15 years three new types of experimental vaccine have been developed: inactivated, attenuated, and recombinant vaccines. These new vaccines have shown varying degrees of promise, but none is as yet sufficiently successful to be marketable. We describe the experimental products, and the various technical and biological difficulties which are being encountered, and report on ways in which new technologies are being used to improve vaccine effectiveness.
\end{abstract}

\section{INTRODUCTION}

Heartwater is a lethal bacterial disease of domestic and some wild ruminants. It is caused by the intracellular rickettsia Ehrlichia ruminantium which is transmitted by ticks of the genus Amblyomma, and the disease is prevalent wherever the tick vectors occur (Provost \& Bezuidenhout 1987). The endemic area includes the whole of sub-Saharan Africa, and also the French Antillean islands of Guadeloupe, Antigua and Marie Galante, to which infected Amblyomma variegatum ticks were introduced probably in the eighteenth century (Maillard \& Maillard 1998). In the sub-Saharan region the disease is one of the major causes of stock losses, and it has been estimated that more than 150 million animals are at risk in the area (Minjauw \& McLeod 2003). Typically the infection causes a high fever, nervous signs, hydropericardium, hydrothorax and oedema of the lungs and brain, and death.
The first known reference to what was subsequently thought to have been heartwater was made in 1838 by Louis Trichardt (Neitz 1947). While trekking through the Northern Province of South Africa many of his sheep died 3 weeks after they had suffered a severe tick infestation. Sixty years later Dixon (1898) and Edington (1898) showed that the disease could be passaged by the transfer of blood from infected to susceptible animals, and Lounsbury (1900) confirmed that the vector in South Africa was Amblyomma hebraeum.

\section{HEARTWATER AT ONDERSTEPOORT}

When the Onderstepoort Veterinary Research Institute was opened in 1908 the Director, Sir Arnold Theiler, had been working on the disease since at least 1904 (Theiler 1904). Theiler continued to work on heartwater, and in 1925 he invited the Canadian 
rickettsiologist Edmund Cowdry to Onderstepoort to investigate the disease. Cowdry demonstrated the causative organism in the tissues of infected ruminants and ticks (Cowdry 1925a, b) and initially he named it Rickettsia ruminantium. The name was later changed to Cowdria ruminantium (Moshkovski 1947) and much more recently molecular phylogenetic evidence has shown that the heartwater agent is in fact a species of Ehrlichia which is now known as E. ruminantium (Dumler, Barbet, Bekker, Dasch, Palmer, Ray, Rikihisa \& Rurangirwa 2001).

Work on heartwater has continued at Onderstepoort up until the present day, and some notable advances have been made. In 1945 the introduction of antibiotics led to the development of a method of control by infection and treatment which is still in use (Neitz \& Alexander 1945). In 1985 a technique for the continuous in vitro culture of the organism was introduced after at least 50 years of effort (Bezuidenhout, Paterson \& Barnard 1985). Most recently the sequencing and annotation of the E. ruminantium genome has been completed (Collins et al. 2005), the first whole genome to be determined in Africa. Two new experimental vaccines have also been developed during recent years, a recombinant vaccine in 2003 (Collins, Pretorius, Van Kleef, Brayton, Allsopp, Zweygarth \& Allsopp 2003) and an attenuated vaccine in 2005 (Zweygarth, Josemans, Van Strijp \& Steyn 2005).

\section{CONTROL METHODS FOR HEARTWATER}

The current methods used for heartwater control include the use of acaricides to control the tick vector, antibiotic prophylaxis (Peregrine 1994), immunization by infection and treatment (Van der Merwe 1987), farming with animal breeds resistant to the disease (Camus, Maillard, Ruff, Pepin, Naves \& Matheron 1996), and establishment of endemic stability (Tice, Bryson, Stewart, Du Plessis \& De Waal 1998). All of these methods have serious drawbacks. Prophylactic antibiotic treatment is widely used by commercial Angora goat farmers in the Eastern Cape Province of South Africa because these animals are highly susceptible to heartwater. It is, however, a very expensive option, the logistics are daunting and there is always the likelihood that antibiotic resistance may develop. Tick control with acaricides, although also expensive, has been in use for more than a century (Dixon 1899) and it was in the past very effective. Today, however, acaricide resistance is widespread and the environmental pollution caused by the chemicals is generally de- plored. Also of serious concern is the fact that animals undergoing an intensive dipping regimen lose any immunity to the disease and subsequent tick control failures can lead to catastrophic heartwater losses, as occurred in Zimbabwe in the 1970s (Norval 1979). The establishment of endemic stability, using limited dipping to control ticks to manageable levels, can be highly successful, but if herd immunity breaks down then serious disease outbreaks can occur. This can happen if new immunotypes enter an area where immunity to the previously prevalent strains offers no or limited protection, and such a situation is very likely to occur as widespread genetic exchange is known to take place in the field between different strains of E. ruminantium (Allsopp \& Allsopp 2007).

Ultimately the only long term control method which will be cost effective is immunization, and an infection and treatment regimen has been widely used in southern Africa since its development at Onderstepoort in 1945 (Neitz \& Alexander 1945). This 'vaccine' is commercially available and it consists of a cryopreserved preparation of blood taken from a sheep infected with virulent $E$. ruminantium organisms of the Ball 3 genotype (Haig 1952). The blood is injected intravenously into the animals to be immunized, their temperatures are monitored daily, and antibiotic treatment is administered when the infection becomes established, but before serious disease occurs. There are several practical disadvantages to this procedure. Firstly, E. ruminantium organisms rapidly lose infectivity even at $4^{\circ} \mathrm{C}$ (Brayton, Collins, Van Strijp \& Allsopp 2003), so the infective blood must be preserved on dry ice and thawed immediately before inoculation which makes the infection and treatment method inappropriate for use in rural areas. Secondly, the procedure must be supervised by trained staff because of the need for intravenous injection and subsequent careful monitoring of the animals' condition. Thirdly, because live organisms are involved the procedure cannot be used in areas where heartwater is not endemic. The most serious disadvantage, however, is that the duration and effectiveness of immunity is uncertain. The Ball 3 genotype used in this procedure is known to offer only limited protection against some common virulent genotypes (Collins et al. 2003). However, because Ball 3 produces a temperature rise two or three days before serious disease is established it is unlikely to lead to stock deaths during the immunization procedure, whereas other common virulent genotypes like Welgevonden (Du Plessis, Van Gas, Olivier \& Bezuidenhout 1989) can cause death very shortly after a rapid tempera- 
ture rise and are therefore not suitable for use in infection and treatment.

\section{DEVELOPMENT OF IMPROVED VACCINES}

There are three possible types of improved vaccine each of which has received extensive attention from researchers: inactivated, live attenuated, and recombinant. We will survey recent developments and future prospects for all three types.

\section{Inactivated vaccines}

The first inactivated heartwater vaccine, developed in Guadeloupe using the Gardel strain of E. ruminantium, was prepared from elementary bodies partially purified from tissue culture material and chemically inactivated using sodium azide (Martinez, Maillard, Coisne, Sheikboudou \& Bensaid 1994). The vaccine was formulated with Freund's adjuvant and used to immunize goats, each of which received an initial and a booster inoculation. When subsequently challenged with homologous tissue culture material $50-80 \%$ of the animals were found to be protected while $100 \%$ of untreated controls died. The same methodology was later used in Zimbabwe, where the vaccine was prepared using the Crystal Springs strain, inactivated with $\beta$-propiolactone, and also formulated with Freund's adjuvant. This vaccine was used to immunize sheep, each of which received five inoculations over a period of months, and in this case $50-100 \%$ of the animals were protected against a homologous needle challenge which killed $60 \%$ of untreated controls (Mahan, Andrew, Tebele, Burridge \& Barbet 1995). Similar inactivated vaccines have been used over the succeeding 12 years, using different strains of E. ruminantium and different commercially acceptable adjuvants. When a needle challenge with a heterologous strain, or a tick challenge, is given the inactivated vaccines are less protective than in the original experiments (Mahan, Smith, Kumbula Burridge \& Barbet 2001; Faburay, Geysen, Ceesay, Marcelino, Alves, Taoufik, Postigo, Bell-Sakyi \& Jongejan 2007). Protection levels are even lower when the vaccines are tested in the field against a natural tick challenge with organisms of differing immunogenicities. A summary of all the inactivated vaccine field trials conducted by one research group over a period of 8 years showed that overall mortality levels could be reduced, in sheep from $78 \%$ (unvaccinated) to $54 \%$ (vaccinated) and in cattle from $67 \%$ (unvaccinated) to $19 \%$ (vaccinated) (Mahan, Barbet \& Burridge 2003).
One early difficulty with these inactivated vaccines was that large amounts of material had to be used, in multiple inoculations, and the cost of production from tissue culture was unacceptably high. There have, however, been marked improvements in culture technology for E. ruminantium in recent years, which have put commercial vaccine preparation within reach (Marcelino, Sousa, Verissimo, Cunha, Carrondo \& Alves 2006; Marcelino, Vachiery, Amaral, Roldao 2007). The problem that remains to be addressed is the disappointing levels of protection achieved against natural tick challenge in the field, especially in Africa. The high mortalities of vaccinated animals in this situation are likely to be the result of infection with non-cross protecting immunotypes. It is therefore of great significance for vaccine development to note that there is extensive polymorphism between $E$. ruminantium strains, particularly in southern Africa (Allsopp, Van Heerden, Steyn \& Allsopp 2003; Allsopp \& Allsopp 2007), and moreover there is large-scale recombination between the different genotypes (Allsopp, Van Strijp, Faber, Josemans \& Allsopp 2007). So while inactivated vaccines could be useful in the Caribbean, where there is limited genetic variability within the $E$. ruminantium population, it may be difficult to achieve the improvements in protectivity in the African situation which would be required to make these vaccines commercially viable.

\section{Recombinant vaccines}

The observation that inactivated heartwater vaccines can stimulate protective immunity indicates that the development of a successful recombinant vaccine, using selected $E$. ruminantium genes, is theoretically possible. A recombinant vaccine should be cheaper to manufacture, and easier to store than an inactivated vaccine, and recombinant heartwater vaccine development is a very active area of research. The first attempts to develop such a vaccine used the map1 gene of $E$. ruminantium, cloned into an expression vector together with a viral enhancerpromoter, which was tested for its ability to protect mice against a lethal homologous challenge (Nyika, Mahan, Burridge, McGuire, Rurangirwa \& Barbet 1998). Protection levels ranging from $23-88 \%$ were obtained in several different experiments using this naked DNA vector alone, and subsequently attempts were made to improve the protection levels by boosting with recombinant MAP1 protein (Nyika, Barbet, Burridge \& Mahan 2002). This procedure enhanced protection levels in mice from a range of $13-27 \%$ without boosting to a range of $53-67 \%$ with boosting. 
There are some experimental indications that the map1 gene might not be the best choice for recombinant vaccine development. For example, purified MAP1 protein inoculated into goats and a sheep induced high specific antibody titres but conferred no protection against homologous challenge (Van Kleef, Neitz \& De Waal 1993). Then it must be remembered that $E$. ruminantium map1 genes are highly polymorphic (Allsopp, Dorfling, Maillard, Bensaid, Haydon, Van Heerden \& Allsopp 2001) so any vaccine using this gene would have to include variants of all important virulent strains. The complete E. ruminantium genome contains 888 annotated genes (Collins et al. 2005), any of which are potentially available for use in experimental vaccines, however identifying those which code for antigens which stimulate the required protective T-cell response is not a trivial exercise (Esteves et al. 2004). One research group has attempted to identify suitable genes by screening $E$. ruminantium expression libraries (Barbet, Whitmire, Kamper, Simbi, Ganta, Moreland, Mwangi, McGuire \& Mahan 2001). Clones were selected whose expression products were both recognized by anti- $E$. ruminantium antibodies and also stimulated proliferation of peripheral blood mononuclear cells (PBMC) from cattle immunised against $E$. ruminantium by infection and treatment. The selected clones were expressed in recombinant bacteria and pools of bacterial lysates containing the $E$. ruminantium gene products were used to immunize mice. Some pools of recombinants stimulated protective immunity against homologous challenge in 58-89\% of the immunized mice, levels of protection which were no improvement on those obtained using the map1 gene.

A striking feature of all the E. ruminantium immunization trials in mice discussed above is the highly variable levels of immunity which were reported. Even more problematic is the observation that some genes confer immunity in the mouse model but this protection is not reproducible in ruminants (Louw, Brayton, Collins, Pretorius, Van Strijp \& Allsopp 2002; Collins et al. 2003). These observations led one laboratory to begin conducting all E. ruminantium vaccination trials in sheep, and the results have been much more reproducible. In some of the most successful experiments a cocktail of four E. ruminantium genes, cloned in a DNA vaccine vector and used to immunize sheep, was found to stimulate complete protection against a virulent needle challenge with both homologous, and five different heterologous, E. ruminantium strains (Collins et al. 2003). This experimental vaccination was, however, not very effective when used in the field against a natural heartwater-infected tick challenge, when levels of protection only reached $20 \%$.

The four genes in the protective cocktail are thought to be components of an $A B C$ transporter system but it was not known whether the protection which they offered was specific to their function. The map1 gene had been shown to provide some protection when presented as a DNA vaccine, even though there were reasons to believe that it might not be a good choice for recombinant vaccine development, so further work was carried out to determine how the protection stimulated by the putative $A B C$ transporter genes compared with that stimulated by other cocktails of E. ruminantium genes (Pretorius, Collins, Steyn, Van Strijp, Van Kleef \& Allsopp 2007). The protection was shown to be specific to the ABC transporter genes, since cocktails of other E. ruminantium ORFs presented in the same vaccine system failed to provide any protection. Furthermore, the levels of protection stimulated by each of the putative $A B C$ transporter genes presented individually was similar to that stimulated by the four-gene cocktail. The protection against field challenge remained poor, however, and this appeared to be a result of markedly enhanced virulence of E. ruminantium organisms injected by the tick, as compared to those which are present in infected mammalian blood (Pretorius et al. 2007).

Heterologous prime-boosting is a well tried strategy for improving DNA vaccine protection levels, it involves boosting the initial immunity with recombinant protein or a recombinant viral vaccine vector (Vordermeier, Lowrie \& Hewinson 2003; Gilbert et al. 2006) Enhancing the protection levels of the experimental E. ruminantium recombinant vaccine has been attempted by boosting with either recombinant protein or recombinant lumpy skin disease virus (LSDV) (Pretorius, Van Kleef, Collins, Tshikudo, Louw, Faber, Van Strijp \& Allsopp 2008). Recombinant protein boosting appeared to be more efficient than boosting with rLSDV, since only lymphocytes isolated from animals which received the protein boost showed specific proliferation and increased interferon gamma expression when exposed to the recombinant $E$. ruminantium proteins. Complete protection against an experimental needle challenge was retained, but the levels of protection against an infected tick challenge in the field were not improved at all.

In summary, the development of a recombinant vaccine shows great promise, especially when using a prime-boost configuration, but there are problems to be resolved. The algorithms used for selecting 
vaccine candidate genes in silico are currently unreliable, and in vivo stimulation of cytokine secretion or T-cell responses does not correlate with the protective ability of genes. It is also evident that protection against a needle challenge is not a reliable predictor of immunity against a natural tick challenge, so a way must be found to implement a laboratorybased tick challenge to simulate the natural situation in a controlled environment. It is also important to note that candidate vaccines must be tested in ruminants, since tests in the mouse model do not give reproducible results nor can the findings be reliably extrapolated to predict how the vaccine will behave in ruminants.

\section{Attenuated vaccines}

Attenuated vaccines are the oldest form of vaccine, and as they are based on pathogens which cause no clinical disease, but which retain their immunogenic properties, they can stimulate solid long-lasting immunity. The main difficulty is that traditional methods for attenuating virulent organisms are imprecise processes which take indeterminate lengths of time. The first strain of E. ruminantium to be attenuated was the Senegal strain, which attenuated after culture in endothelial cells over 11 passages and 239 days (Jongejan 1991). When inoculated into sheep and goats the attenuated organism caused no clinical reaction and the animals were completely protected against a subsequent homologous needle challenge. When field trials were conducted, however, the protection levels were lower, with reductions in mortality, as compared to unvaccinated controls, from $70-43 \%$ in one study (Gueye, Jongejan, Mbengue, Diouf \& Uilenberg 1994), and from 100-25\% in another (Faburay et al. 2007).

Immunity to the Senegal strain provides limited protection against other E. ruminantium strains (Jongejan, Thielemans, Briere \& Uilenberg 1991) while the Welgevonden strain, in contrast, provides good cross-protection against a range of other virulent strains (Collins et al. 2003). In principle, therefore, the Welgevonden strain would be a much better candidate from which to develop an attenuated vaccine, but unfortunately it failed to attenuate after culture through hundreds of passages over several years (Gueye et al. 1994; Zweygarth, Vogel, Josemans \& Horn 1997).

A common technique to induce attenuation of a pathogen is to culture it in an abnormal host cell, and the Welgevonden strain was induced to infect a canine macrophage-monocyte cell line (DH82) by adding cycloheximide to the culture medium in order to slow the metabolism of the host cells. After continuous propagation in DH82 cells the organism was found to have lost all virulence for mice between passages 25 and 50 . Since DH82 cells are cancerous and not suitable for vaccine use the attenuated strain was re-adapted to bovine endothelial cells after 61 passages in DH82 cells (Zweygarth et al. 2005). When the re-adapted attenuated Welgevonden strain was used to infect sheep or goats there was a brief rise in body temperature, without any other adverse symptoms, and the animals were subsequently found to be fully protected against a lethal needle challenge with both the homologous, and four different heterologous, E. ruminantium strains (Zweygarth et al. 2005).

Further testing of this promising attenuated vaccine has been undertaken (Zweygarth, Josemans, Van Strijp \& Steyn 2008) and a summary of the results in different ruminant species, administered by different routes, is shown in Table 1. The intravenous route was the most effective, providing $100 \%$ protection in Merino sheep and Boer goats, and while the protection in Angora goats was only $90 \%$ these animals are known to be exceptionally sensitive to E. ruminantium (Du Plessis, Jansen \& Prozesky 1983). The protection rate in cattle was also less than ideal, at $83 \%$, but it should be noted that the

TABLE 1 Immunising ability of attenuated E. ruminantium Welgevonden (after Zweygarth et al. 2008)

\begin{tabular}{|l|l|l|l|c|}
\hline Species & Dose of elementary bodies & Route & Challenge & Protection (\%) \\
\hline Merino sheep & $1.1 \times 10^{5}$ & iv & Homologous & 100 \\
Merino sheep & Various & iv & Heterologous (five different strains) & 100 \\
Merino sheep & $6.7 \times 10^{5}$ & sc & Homologous & 83 \\
Merino sheep & $2.6 \times 10^{5}$ & im & Homologous & 80 \\
Boer goats & Various & iv & Homologous & 100 \\
Angora goats & $0.9 \times 10^{4}-1.3 \times 10^{5}$ & iv & Homologous & 90 \\
Friesian cattle & $1.7 \times 10^{5}-2.2 \times 10^{6}$ & iv & Heterologous (Gardel) & 83 \\
\hline
\end{tabular}

Note: All animals were needle challenged with blood stabilates of virulent E. ruminantium 
cattle were challenged with the Gardel strain, to which they are very sensitive, because they are not particularly sensitive to the Welgevonden strain. Attempts to use an intramuscular or subcutaneous route of inoculation led to less effective protection than when using the intravenous route. Ideally a vaccine would provide lifelong immunity, and some experiments have been conducted to determine the duration of the immunity which this attenuated vaccine provides. So far these have only been carried out in Merino sheep, and the immunity remains at $100 \%$ for at least 6 months, but then falls to $80 \%$ after one year (Zweygarth et al. 2008). It is likely, however, that under normal field conditions the natural heartwater challenge would prevent early loss of immunity.

Estimates made of the possible production costs of this attenuated Welgevonden vaccine suggest that the culture costs for 60 sheep vaccine doses would be around US $\$ 1$. This compares very favourably with the current cost of $\$ 27$ for 60 doses of Ball 3 infected blood for infection and treatment. Further development of this promising attenuated vaccine is needed, and the first priority is to carry out tick challenge experiments on immunized animals. Several commercial vaccine development criteria must also be addressed, such as possible formulation of the vaccine for intramuscular or subcutaneous inoculation, which would be much more convenient that the intravenous route, and testing of retention of effectiveness after lyophilization, since a lyophilized vaccine would not need a cold chain for distribution.

The perennial concern with attenuated vaccines is the possibility that they may revert to virulence, perhaps as the result of recombination in the field with wild types of the pathogen. This, however, is not of major consequence in the endemic area, since new genes would not be added to the existing environment and widespread recombination between strains is already known to occur. Obviously this attenuated vaccine would not be useable in non-endemic areas, but it would be an excellent stopgap vaccine for use in Africa pending the development of a recombinant vaccine.

\section{SUMMARY}

The last ten years have seen the most significant developments in E. ruminantium vaccination since the introduction of the infection and treatment procedure in 1945, with exciting advances in both recombinant and attenuated vaccines. A recombinant vaccine would be the ideal solution to heartwater control, especially for export, since it would be useable anywhere in the world. This would be essential in the event of any spread of the disease outside the current endemic area, such as the long feared possibility of a cattle egret mediated spread of heartwater infected ticks from the Lesser Antilles to the American mainland (Deem 1998). Another advantage of a recombinant vaccine would be the relative ease with which the evolution of vaccine genes in the wild could be followed, allowing the vaccine formulation to be changed to keep up with pathogen changes. The research needed to develop a recombinant vaccine is, however, likely to be relatively time-consuming and expensive, and in the interim the new attenuated Welgenvonden vaccine shows great promise. The development of this vaccine to the level of commercialization should be undertaken as a matter of urgency.

\section{ACKNOWLEDGEMENTS}

I would like to thank all my colleagues and collaborators with whom I have worked on heartwater during the last 17 years. My thanks go, in alphabetical order, to the following: Dr Maria Allsopp, Dr Kelly Brayton, Dr Nicola Collins, Dr Etienne de Villiers, Ms Erika Faber, Prof. Frans Jongejan, Mrs Antoinette Josemans, Prof. Fourie Joubert, Ms Junita Liebenberg, Ms Elmarié Louw, Dr Alri Pretorius, Ms Helena Steyn, Dr Henriette van Heerden, Dr Mirinda van Kleef, Ms Fransie van Strijp and Dr Erich Zweygarth.

\section{REFERENCES}

ALLSOPP, M.T., DORFLING, C.M., MAILLARD, J.C., BENSAID, A., HAYDON, D.T., VAN HEERDEN, H. \& ALLSOPP, B.A. 2001. Ehrlichia ruminantium major antigenic protein gene (map1) variants are not geographically constrained and show no evidence of having evolved under positive selection pressure. Journal of Clinical Microbiology, 39:4200-4203.

ALLSOPP, M.T., VAN HEERDEN, H., STEYN, H.C. \& ALLSOPP, B.A. 2003. Phylogenetic relationships among Ehrlichia ruminantium isolates. Annals of the New York Academy of Sciences, 990:685-691.

ALLSOPP, M.T. \& ALLSOPP, B.A. 2007. Extensive genetic recombination occurs in the field between different genotypes of Ehrlichia ruminantium. Veterinary Microbiology, 124:5865.

ALLSOPP, M.T., VAN STRIJP, M.F., FABER, E., JOSEMANS, A.I. \& ALLSOPP, B.A. 2007. Ehrlichia ruminantium variants which do not cause heartwater found in South Africa. Veterinary Microbiology, 120:158-166.

BARBET, A.F., WHITMIRE, W.M., KAMPER, S.M., SIMBI, B.H., GANTA, R.R., MORELAND, A.L., MWANGI, D.M., McGUIRE, T.C. \& MAHAN, S.M. 2001. A subset of Cowdria ruminantium genes important for immune recognition and protection. Gene, 275:287-298. 
BEZUIDENHOUT, J.D., PATERSON, C.L. \& BARNARD, B.J. 1985. In vitro cultivation of Cowdria ruminantium. Onderstepoort Journal of Veterinary Research, 52:113-120.

BRAYTON, K.A., COLLINS, N.E., VAN STRIJP, F. \& ALLSOPP, B.A. 2003. Preparation of Ehrlichia ruminantium challenge material for quantifiable and reproducible challenge in mice and sheep. Veterinary Parasitology, 112:63-73.

CAMUS, E., MAILLARD, J.C., RUFF, G., PEPIN, L., NAVES, M. \& MATHERON, G. 1996. Genetic resistance of Creole goats to cowdriosis in Guadeloupe. Status in 1995. Annals of the New York Academy of Sciences, 791:46-53.

COLLINS, N.E., PRETORIUS, A., VAN KLEEF, M., BRAYTON, K.A., ALLSOPP, M.T., ZWEYGARTH, E. \& ALLSOPP, B.A. 2003. Development of improved attenuated and nucleic acid vaccines for heartwater. Developmental Biology (Basel), 114:121-136.

COLLINS, N.E., LIEBENBERG, J., DE VILLIERS, E.P., BRAYTON, K.A., LOUW, E., PRETORIUS, A., FABER, F.E., VAN HEERDEN, H., JOSEMANS, A., VAN KLEEF, M., STEYN, H.C., VAN STRIJP, M.F., ZWEYGARTH, E., JONGEJAN, F., MAILLARD, J.C., BERTHIER, D., BOTHA, M., JOUBERT, F., CORTON, C.H., THOMSON, N.R., ALLSOPP, M.T. \& ALLSOPP, B.A. 2005. The genome of the heartwater agent Ehrlichia ruminantium contains multiple tandem repeats of actively variable copy number. Proceedings of the National Academy of Sciences of the United States of America, 102: 838-843.

COWDRY, E.V. 1925a. Studies on the etiology of heartwater 1. Observation of a rickettsia, Rickettsia ruminantium (n. sp.), in the tissues of infected animals. Journal of Experimental Medicine, 42:231-252.

COWDRY, E.V. 1925b. Studies on the etiology of heartwater 2. Rickettsia ruminantium (n. sp.) in the tissues of ticks transmitting the disease. Journal of Experimental Medicine, 42: 253-274.

DEEM, S.L. 1998. A review of heartwater and the threat of introduction of Cowdria ruminantium and Amblyomma spp. ticks to the American mainland. Journal of Zoo and Wildlife Medicine, 29:109-113.

DIXON, R.W. 1898. Heartwater experiments. Agricultural Journal of the Cape of Good Hope, 12:754-760.

DIXON, R.W. 1899. Heartwater experiments. Agricultural Journal of the Cape of Good Hope, 14:205-207.

DU PLESSIS, J.L., JANSEN, B.C. \& PROZESKY, L. 1983. Heartwater in Angora goats. I. Immunity subsequent to artificial infection and treatment. Onderstepoort Journal of Veterinary Research, 50:137-43.

DU PLESSIS, J.L., VAN GAS, L., OLIVIER, J.A. \& BEZUIDENHOUT, J.D. 1989. The heterogenicity of Cowdria ruminantium stocks: cross-immunity and serology in sheep and pathogenicity to mice. Onderstepoort Journal of Veterinary Research, 56:195-201.

DUMLER, J.S., BARBET, A.F., BEKKER, C.P., DASCH, G.A., PALMER, G.H., RAY, S.C., RIKIHISA, Y. \& RURANGIRWA, F.R. 2001. Reorganization of genera in the families Rickettsiaceae and Anaplasmataceae in the order Rickettsiales: unification of some species of Ehrlichia with Anaplasma, Cowdria with Ehrlichia and Ehrlichia with Neorickettsia, descriptions of six new species combinations and designation of Ehrlichia equi and 'HGE agent' as subjective synonyms of Ehrlichia phagocytophila. International Journal of Systematics and Evolution in Microbiology, 51:2145-2165.

EDINGTON, A. 1898. Heartwater. Agricultural Journal of the Cape of Good Hope, 12:748-754.
ESTEVES, I., VACHIERY, N., MARTINEZ, D. \& TOTTE, P. 2004. Analysis of Ehrlichia ruminantium-specific T1/T2 responses during vaccination with a protective killed vaccine and challenge of goats. Parasite Immunology, 26:95-103.

FABURAY, B., GEYSEN, D., CEESAY, A., MARCELINO, I., ALVES, P.M., TAOUFIK, A., POSTIGO, M., BELL-SAKYI, L. \& JONGEJAN, F. 2007. Immunisation of sheep against heartwater in The Gambia using inactivated and attenuated Ehrlichia ruminantium vaccines. Vaccine, 25:7939-7947.

GILBERT, S.C., MOORTHY, V.S., ANDREWS, L., PATHAN, A.A., MCCONKEY, S.J., VUOLA, J.M., KEATING, S.M., BERTHOUD, T., WEBSTER, D., MCSHANE, H. \& HILL, A.V. 2006. Synergistic DNA-MVA prime-boost vaccination regimes for malaria and tuberculosis. Vaccine, 24:4554-61.

GUEYE, A., JONGEJAN, F., MBENGUE, M., DIOUF, A. \& UILENBERG, G. 1994. Essai sur le terrain d'un vaccin atténué contre la cowdriose. Revue d'Elevage et de Médecine Vétérinaire des Pays Tropicaux, 47:401-404.

HAIG, D.A. 1952. Note on the use of the white mouse for the transport of strains of heartwater. Journal of the South African Veterinary Medical Association, 23:167-170.

JONGEJAN, F. 1991. Protective immunity to heartwater (Cowdria ruminantium infection) is acquired after vaccination with in vitro-attenuated rickettsiae. Infection and Immunity, 59:729731.

JONGEJAN, F., THIELEMANS, M.J., BRIERE, C. \& UILENBERG, G. 1991. Antigenic diversity of Cowdria ruminantium isolates determined by cross-immunity. Research in Veterinary Science, 51:24-28.

LOUNSBURY, C.P. 1900. Tick heartwater experiments. Agricultural Journal of the Cape of Good Hope, 16:682-687.

LOUW, E., BRAYTON, K.A., COLLINS, N.E., PRETORIUS, A., VAN STRIJP, F. \& ALLSOPP, B.A. 2002. Sequencing of a 15-kb Ehrlichia ruminantium clone and evaluation of the cpg1 open reading frame for protection against heartwater. Annals of the New York Academy of Sciences, 969:147-150.

MAHAN, S.M., ANDREW, H.R., TEBELE, N., BURRIDGE, M.J. \& BARBET, A.F. 1995. Immunisation of sheep against heartwater with inactivated Cowdria ruminantium. Research in Veterinary Science, 58:46-49.

MAHAN, S.M., SMITH, G.E., KUMBULA, D., BURRIDGE, M.J. \& BARBET, A.F. 2001. Reduction in mortality from heartwater in cattle, sheep and goats exposed to field challenge using an inactivated vaccine. Veterinary Parasitology, 97:295-308.

MAHAN, S.M., BARBET, A.F. \& BURRIDGE, M.J. 2003. Development of improved vaccines for heartwater. Developmental Biology (Basel), 114:137-145.

MAILLARD, J.C. \& MAILLARD, N. 1998. Historique du peuplement bovin et de l'introduction de la tique Amblyomma variegatum dans les îles françaises des Antilles: Synthèse bibliographique. Ethnozootechnie, 1:19-36.

MARCELINO, I., SOUSA, M.F., VERISSIMO, C., CUNHA, A.E., CARRONDO, M.J. \& ALVES, P.M. 2006. Process development for the mass production of Ehrlichia ruminantium. Vaccine, 24:1716-1725. E-pub 14 Oct 2005.

MARCELINO, I., VACHIERY, N., AMARAL, A.I., ROLDAO, A., LEFRANCOIS, T., CARRONDO, M.J., ALVES, P.M. \& MARTINEZ, D. 2007. Effect of the purification process and the storage conditions on the efficacy of an inactivated vaccine against heartwater. Vaccine, 25:4903-4913. E-pub 7 May 2007.

MARTINEZ, D., MAILLARD, J.C., COISNE, S., SHEIKBOUDOU, C. \& BENSAID, A. 1994. Protection of goats against heart- 
water acquired by immunisation with inactivated elementary bodies of Cowdria ruminantium. Veterinary Immunology and Immunopathology, 41:153-163.

MINJAUW, B. \& McLEOD, A. Tick-borne diseases and poverty. The impact of ticks and tick-borne diseases on the livelihood of small-scale and marginal livestock owners in India and eastern and southern Africa. 2003. Edinburgh, UK, Research Report, DFID Animal Health Programme, Centre for Tropical Veterinary Medicine, University of Edinburgh.

MOSHKOVSKI, S.D. 1947. Comments by readers. Science, 106: 62.

NEITZ, W.O. \& ALEXANDER, R.A. 1945. Immunization of cattle against heartwater and the control of the tick-borne diseases, redwater, gallsickness and heartwater. Onderstepoort Journal of Veterinary Science and Animal Industry, 20:137158.

NEITZ, W.O. 1947. The transmission of heartwater by Amblyomma pomposum Dönitz, 1909. South African Journal of Science, 1:83.

NORVAL, R.A. 1979. Tick infestations and tick-borne diseases in Zimbabwe Rhodesia. Journal of the South African Veterinary Association, 50:289-92.

NYIKA, A., MAHAN, S.M., BURRIDGE, M.J., McGUIRE, T.C., RURANGIRWA, F. \& BARBET, A.F. 1998. A DNA vaccine protects mice against the rickettsial agent Cowdria ruminantium. Parasite Immunology, 20:111-119.

NYIKA, A., BARBET, A.F., BURRIDGE, M.J. \& MAHAN, S.M. 2002. DNA vaccination with map1 gene followed by protein boost augments protection against challenge with Cowdria ruminantium, the agent of heartwater. Vaccine, 20:12151225.

PEREGRINE, A.S. 1994. Chemotherapy and delivery systems: haemoparasites. Veterinary Parasitology, 54:223-48.

PRETORIUS, A., COLLINS, N.E., STEYN, H.C., VAN STRIJP, F., VAN KLEEF, M. \& ALLSOPP, B.A. 2007. Protection against heartwater by DNA immunisation with four Ehrlichia ruminantium open reading frames. Vaccine, 25:2316-2324.

PRETORIUS, A., VAN KLEEF, M., COLLINS, N.E., TSHIKUDO, N., LOUW, E., FABER, F.E., VAN STRIJP, M.F. \& ALLSOPP,
B.A. 2008. A heterologous prime/boost immunisation strategy protects against virulent $E$. ruminantium Welgevonden needle challenge but not against tick challenge. Vaccine, 26 : 4363-4371.

PROVOST, A. \& BEZUIDENHOUT, J.D. 1987. The historical background and global importance of heartwater. Onderstepoort Journal of Veterinary Research, 54:165-169.

THEILER, A. 1904. A contribution to the diagnosis of heartwater in cattle. Transvaal Agricultural Journal, 2:163-173.

TICE, G.A., BRYSON, N.R., STEWART, C.G., DU PLESSIS, B. \& DE WAAL, D.T. 1998. The absence of clinical disease in cattle in communal grazing areas where farmers are changing from an intensive dipping programme to one of endemic stability to tick-borne diseases. Onderstepoort Journal of Veterinary Research, 65:169-75.

VAN DER MERWE, L. 1987. The infection and treatment method of vaccination against heartwater. Onderstepoort Journal of Veterinary Research, 54:489-491.

VAN KLEEF, M., NEITZ, A.W. \& DE WAAL, D.T. 1993. Isolation and characterization of antigenic proteins of Cowdria ruminantium. Revue d'Elevage et de Médecine Vétérinaire des Pays Tropicaux, 46 :157-164.

VORDERMEIER, H.M., LOWRIE, D.B. \& HEWINSON, R.G. 2003. Improved immunogenicity of DNA vaccination with mycobacterial HSP65 against bovine tuberculosis by protein boosting. Veterinary Microbiology, 93:349-59.

ZWEYGARTH, E., VOGEL, S.W., JOSEMANS, A.I. \& HORN, E. 1997. In vitro isolation and cultivation of Cowdria ruminantium under serum-free culture conditions. Research in Veterinary Science, 63:161-164.

ZWEYGARTH, E., JOSEMANS, A.I., VAN STRIJP, M.F., LOPEZ-REBOLLAR, L., VAN KLEEF, M. \& ALLSOPP, B.A. 2005. An attenuated Ehrlichia ruminantium (Welgevonden stock) vaccine protects small ruminants against virulent heartwater challenge. Vaccine, 23:1695-1702.

ZWEYGARTH, E., JOSEMANS, A.I., VAN STRIJP, F.M. \& STEYN, H.C. 2008. Experimental use of the attenuated Ehrlichia ruminantium (Welgevonden) vaccine in Merino sheep and Angora goats. Vaccine, in press. 